\title{
Kernos
}

Revue internationale et pluridisciplinaire de religion grecque antique

$24 \mid 2011$

Varia

\section{Synoecism and religious interface in Demetrias (Thessaly)}

Sofia Kravaritou

\section{OpenEdition \\ Journals}

Electronic version

URL: http://journals.openedition.org/kernos/1942

DOI: 10.4000/kernos. 1942

ISSN: 2034-7871

\section{Publisher}

Centre international d'étude de la religion grecque antique

\section{Printed version}

Date of publication: 1 January 2011

Number of pages: 111-135

ISSN: 0776-3824

\section{Electronic reference}

Sofia Kravaritou, «Synoecism and religious interface in Demetrias (Thessaly) ", Kernos [Online], 24 | 2011, Online since 01 February 2014, connection on 01 May 2019. URL : http:// journals.openedition.org/kernos/1942; DOI : 10.4000/kernos.1942 


\title{
Synoecism and religious interface in Demetrias (Thessaly)*
}

\begin{abstract}
This paper addresses the issues related to the contribution of archaeology along with other disciplines, mostly history and epigraphy, to the study of the re-structuring of religious life within the confines of post-classical synoecisms. Emphasis is placed on the religious interface of eastern coastal Thessaly, as it was configured after the local communities came together to form a new royal foundation, Demetrias, in 293.

Résumé : Cet article aborde les questions liées à l'apport de l'archéologie avec d'autres disciplines, principalement l'histoire et l'épigraphie, à l'étude de la réorganisation de la vie religieuse au sein de synécismes post-classiques. L'accent est mis sur l'interface religieuse de Thessalie côti' re de l'Est, tel qui a été configuré apr's la réunion des communautés locales, en 293, afin de former Démétrias, nouvelle fondation royale et si' ge du royaume macédonien.
\end{abstract}

"Can we talk about an Archaeology of Greek Religion?" From this key question addressed by A. Schnapp 1 in 1999 - in an attempt to re-evaluate the hermeneutical and practical dimension of religious archaeology for ancient Greece - until the establishment of Kernos' Archaeological Chronicle in 2001 and its present decennial anniversary celebration, the contribution which archaeology can make to our understanding of Greek religion was more than ever highlighted.

\section{Religion and synoecism}

New types of political organization - namely the enforced or the voluntary synoecism and the sympolity - emerged in a wide scale at the dawn of the classical world, when the restructuring of the socio-political order dynamically overshadowed the classical polis' saga; ${ }^{2}$ this has surely left important traces on the local religious life. The religious inferences of synoecism have been already

${ }^{*}$ I am indebted to the anonymous referee for very constructive criticism. Professor Robert Parker read and commented upon an earlier draft; Dr. Maria Stamatopoulou generously provided comments on the final draft; also Dr. Miltiades Hatzopoulos brought to my attention Demetrius' royal letter and kindly read the final draft. I am grateful to all of them. All errors are due to the author. All dates are BC, unless otherwise indicated.

${ }^{1}$ SCHNAPP (1999), p. 34.

2 On early synoecisms: GABRIELSEN (2000), p. 177-206; Reger (2001), p. 157-181; HANSEN (2004), p. 115-119. For post-classical evidence: COHEN (1995), passim; REGER (2004), p. 145-180. 
briefly discussed by M.P. Nilsson, ${ }^{3}$ but a thorough response to the question of the impact of communities' coalescence to the local religious life has been recently provided by R. Parker: "every re-structuring of the political order required or potentially required the re-organisation of cults, rewriting of sacrificial calendars, re-assignation of priesthoods ... for a community threatened by subjection, aspiring to liberation or contemplating synoecism the future of ancestral cults must have been one very sensitive issue." 4 And this is by no means a modern assumption, since local inscriptions reflect the Greek attitude towards political unification and cultic realignment: an emotional bewilderment and anticipation followed by further drastic enactment.

The Myconian "sacred law" of the last quarter of the third century inaugurates a new era in the creation of the island's religious life after the synoecism. ${ }^{5}$ Furthermore, "no one participate in the rites of Lindos who did not participate in them before" clearly echoes the voice of the Lindians of the late fourth century, after the synoecism of the three Rhodian cities; 6 they clearly approved exclusivity in their own religious affairs and accept no further pan-Rhodian interference or participation in them. ${ }^{7}$ Contrary to such efforts to protect traditional identity, elsewhere the new citizens were to participate in the traditional rites or in all affairs of the existing ones. ${ }^{8}$ This is how, for example, in the first half of the fourth century, the "Heliswasians are to become like and equal to Mantineans", while at least some of their own rites will continue to be performed. ${ }^{9}$ Furthermore, in the liberal polity of the sympolity agreement between Stiris and Medeon in Phocis, in the second century, "the Medeonians are to participate in all Stirian sacrifices and the Stirians to the Medeonian ones." 10 These are only some aspects of a wide range of religious impacts of synoecism and sympolity cases included in Parker's exhaustive case study and appendix, based on diverse forms of a relationship of dependency between communities, with examples of earlier rituals' exclusion or investment of religious emotion on new deities. ${ }^{11}$

However, political unification for the post-classical world was more than an issue involving direct agreement policy between the implicated parts, since many poleis foundations or re-foundations resulted from the decisions of the

\footnotetext{
${ }^{3}$ NiLSSON (1951), p. 18-25.

4 PARKer (2009), p. 183.

5 Syll. ${ }^{3}$, 1024; cf. Reger (2001), p. 157-181. PARKer (2009), p. 188.

${ }^{6}$ IG XII 1, 761, 1. 38-43; PARKER (2009), p. 205-210.

7 GABRiELSEN (2000), p. 177-206.

${ }^{8}$ Cf. PARKer (2009), p. 189-190.

9 SEG 37, 340; THÜr, TAuber (1994), 9 (Translation: PARKer [2009], p. 199).

${ }^{10}$ IG IX 1, 32. Cf. PARKER (2009), p. 201-202.

11 PARKER (2009), p. 183-214.
} 
Hellenistic rulers. ${ }^{12}$ In that case, unions' establishment was depending on instructions codified by the rulers themselves, which in the form of royal letters were dispatched to the local representatives of the royal court, or the magistrates of the implicated cities. ${ }^{13}$ Those instructions included also stipulations on the organization and re-establishment of a normal course in the religious life within the newly established communities. In the first mutilated lines of a letter of Antigonos Monophthalmos to Teos in 303, ordering physical synoecisn between Teos and Lebedos, it is prescribed that the Lebedian delegate to Panionion should "tent and celebrate" with those coming from Teos and "should be called Tean himself." 14

Unfortunately, the fragmentary character of the available documentation often deprives us from those specific instructions on the restructuring of the religious life. This is obviously the case of the fragmentary letter of Antiochos III to the Sardians, in 213, ordering the cutting of wood for the "synoikismos of the city," 15 as well as of a letter of Attalus I (?) to Mylasa ratifying sympolity with Chalcetor (228-223?). ${ }^{16}$

In general, royal correspondence ordering synoecism should be considered as the beginning of a ruler's usual interference in the local religious affairs following the creation of these post-classical royal foundations. An example is the diagramma ordering proper administration of the incomes of Sarapis in the Serapeion of Thessalonike in Macedonia (187), as well as the royal letter to the epistates of Demetrias in Thessaly prescribing the proper clothing to be worn by the royal hunters of Heracles Kynagidas (221-179), both issued by Philip V. ${ }^{17}$

However, due to the lack of adequate epigraphic documentation establishing the religious affairs of every political union, the decryption of the particular type of local poleis coalescence and ritual life usually requires the combination of additional elements to a simple reading of a literary passage, especially when the literary testimonies usually postdate the union itself, not to mention the overlap between the two terms of synoikismos and sympoliteia. ${ }^{18}$

In Thessaly, for example, although literary evidence demonstrates a certain number of political coalescences, especially following the establishment of the Macedonians in the region during the fourth and third century, ${ }^{19}$ only one epigraphic document is known to refer to them: the sympolity agreement

12 COHEN (1995); MA (1999), p. 106-179; Reger (2004), p. 732-793.

13 Welles (1934); Hatzopoulos (2006), p. 82-92.

14 Syll. 33 344, 1-4; SEG 15, 717, 1-4; WeLLES (1934), nos. 3-4; PARKER (2009), p. 200.

15 SEG 39, 1283. Cf. MA (1999), p. 284-285.

16 WeLLES (1934), no. 29.

${ }_{17}$ IG X 2, 1, 3 (diagramma); $f$. Hatzopoulos (1996), no. 15. IntZesiloglou (2006), p. 67-77 (royal letter).

18 Hansen (2004), 115-119. Cf. Reger (2004), p. 148-149; Parker (2009), p. 187.

${ }^{19}$ Cf. Cohen (1995), p. 109-120; HeLly (2009), p. 342-344. 
between Gomphoi and Ithome in NW Thessaly. ${ }^{20}$ On the contrary, in eastern Thessaly, there is a lack of documents negotiating this issue and thus complementary information resulting from the local archaeological data comes in assistance.

\section{The synoecism of Demetrias under Macedonian rule}

In the beginning of the third century (293), the Macedonian king Demetrius Poliorketes established a synoecism of the former Thessalian and Magnesian communities situated around the port of the Pagasetic Gulf and in the Magnesian peninsula respectively and created Demetrias at the inlet of the Gulf. ${ }^{21}$ According to later literary sources, this powerful city and cosmopolitan harbour was meant to constitute a "seat of the Macedonian kingdom (basileion)", a "naval base" and one of the three "fetters" of Greece, along with Corinth and Chalcis. ${ }^{22}$ Following the issues related specifically to the re-organization of the local religious life after this large scale re-structuring of political order in eastern Thessaly at the dawn of the Hellenistic period will be addressed.

\subsection{The royal letter}

Unfortunately, the assignment to identify the nature of Demetrius' synoecism is not provided with an explicit royal document, as - for example - the one ordering the synoecism between Lebedos and Teos. ${ }^{23}$ However, a relevant although fragmentary - royal letter was discovered in the sanctuary of Zeus Olympios at Dion and was originally assigned to Philip V. ${ }^{24}$ Hatzopoulos has recently re-dated this document to 291 and assigned it to Demetrius Poliorcetes, linking it with the establishment of Demetrias, in 293: "King Demetrius to Ladamas (?), greeting. I have established the delimitation of the territory belonging to the citizens of Demetrias and Pherai, as they have confined it to me." 25 In this letter Demetrius actually commissions the border and landmarks between the territories of Pherai and the newly established Demetrias, ordering a certain Ladamas to put a landmark near the site called Iolkia.

This document constitutes an important piece of evidence with regards to the local topography, especially after its new dating (291). Although the actual royal order of the "how to do it" towards the foundation of the synoecism is missing,

\footnotetext{
${ }^{20}$ Helly (1993), p. 167-200.

${ }^{21}$ Cohen (1995), p. 111-114; Batziou-Efstathiou (2002).

22 Strabo, IX, 4, 15; IX, 5, 15; cf. Livy, XXXII, 37, 3; cf., StÄHLIn, MeYer, HeIdner (1934), p. 137-55; BATZiou-EFSTATHiou (2002); COHEN (1995), p. 111-14.

23 SEG 15, 717, 1-4.

24 Pantermalis (1999), p. 57 (photo); cf. Hatzopoulos (1996), p. 401-403.

${ }^{25}$ Hatzopoulos (2006), p. 88-89 and pl. XIVa (with French translation adapted here); $c$. Bull. Epigr. (2000), p. 453, 5.
} 
Demetrius' letter delimitates the geo-political framework of the new royal foundation vis-à-vis the Thessalian inland and the territory of Pherai, the prominent neighbouring polis of the Thessalian tetras Pelasgiotis. ${ }^{26}$

In particular, Pherai's territorial expansion had for long reached the coastline of the Pagasetic Gulf. It is generally agreed that the poleis located around the harbor of the inlet were, at least from the sixth century, subjects to the Thessalians, ${ }^{27}$ whereas there was no community belonging to the Magnesians before the middle of the fourth century. ${ }^{28}$ Herodotus mentions that Iolkos was already under the control of the Thessalians who offered it to the Athenian tyrant Hippias, ${ }^{29}$ while other sources acknowledge Pagasai as the port of Pherai. ${ }^{30}$ However, in the fourth century, Pseudo-Skylax included Iolkos among the Magnesian poleis, ${ }^{31}$ it certainly enjoyed at that time a polis status, since along with Pagasai, they struck coins bearing the ethnics I $\Lambda$ KI $\Omega N$ and $\Pi A \Gamma A \Sigma A I \Omega N$ respectively. ${ }^{32}$ In the middle of the fourth century, these coastal poleis were handed over to the Macedonians. ${ }^{33}$ Philip II fortified the port, Pagasai, and controlled all commercial activities by collecting their taxes, an action that provoked the anger of the Thessalians. ${ }^{34}$

To sum up, the boundary enacted by Demetrius in the beginning of the third century, between the territories of Demetrias and Pherai, eventually promoted the definitive consolidation of the Macedonian control over the port, pushing Pherai towards the inland.

\subsection{Evidence from literary sources}

Most of the surviving evidence that describes the emergence of Demetrias in the geopolitical scenery of the biggest natural harbour in Thessaly consists of literary sources post-dating the foundation itself. Strabo mentions that "Demetrius founded Demetrias nearby the sea, between Neleia and Pagasai, having synoecized (synoikisas) the nearby polichnai, Neleia, Pagasai, Ormenion and also Rhizous, Sepias, Olizon, Boibe and Iolkos, which are now komai of Demetrias." 35 Also, Plutarch states that "Demetrias was created from polichnai

\footnotetext{
26 Decourt, Nielsen, Helly et al. (2004), p. 704.

27 BAKHuizen (1987), p. 321; Helly (2006), esp. p. 146-147.

${ }^{28}$ Helly (2006), esp. p. 158-163.

${ }^{29}$ Herodotus, V, 94.

30 Theopompus, 115 F 53 (ed. JACOBY); Demosthenes, Olynth. I, 12, 22.

31 Pseudo-Skylax, Periplous, 65.

32 LiAMPI (2005), p. 23-40.

33 Cf. Helly (2006), p. 155-158.

34 Demosthenes, I, 22.

35 Strabo, IX, 5, 15.
} 
placed near Iolkos. ${ }^{36}$ These most important, though quite enigmatic, passages deliver names of local small communities (polichnar) participating in the synoecism and becoming komai of Demetrias.

However, other important information is to be found in Skylax, predating the synoecism, and in the much later Pliny; besides the polichnai enumerated by Strabo and Plutarch, some local poleis names have been assigned by them to the Magnesian peninsula. ${ }^{37}$ Then, were those extra poleis included in the synoecism? And, finally, what is the exact number, the location, the names and the status(es) of the synoecized communities?

Unfortunately, the study of the political geography of the small plain on the bay of the Pagasetic Gulf and the Magnesian peninsula as a whole has not reached safe conclusions regarding the identification and location of these settlements, as most identifications are not corroborated by epigraphic evidence, and often contradict each other; ${ }^{38}$ only the fortified city of Demetrias has been securely identified and excavated. ${ }^{39}$ In addition, although the later sources ${ }^{40}$ mention various names that became komai of Demetrias and even though komai are epigraphically attested for other contemporary royal foundations in Macedonia, there is no epigraphic evidence for post-classical komai in the region of Demetrias. ${ }^{41}$ Consequently, the nature of the early synoecism is inadequately understood: was there a physical synoecism involving large/small scale urban relocation and population transfer or a political one? ${ }^{42}$ What happened to the cults of the old communities?

\section{Archaeology, religion and synoecism in Demetrias}

Since most of the settlements involved in the synoecism are not located or securely identified, neither are most of their cult places; 43 this fact deprives us from appreciating the interface of religious life before and within the

\footnotetext{
36 Plutarch, Demosthenes, 53, 7.

${ }^{37}$ Pseudo-Skylax, 65: "Magnesians constitute an ethnos living close to the sea, while their poleis include Iolkos, Methone, Korakai, Spalauthra, Olizon, the port of Issai; outside of the Pagasetic Gulf are located Meliboia, Rhizous, Eyrymenai, Myrai". Plinius, Natural History IV, 9, 16: "Magnesia's poleis are Iolkos, Ormenium, Pyrrha, Methone and Olizon with the promontory of Sepias. We then come to the poleis of Meliboea, Rhizus and Erymnae; the mouth of Peneus, the polis of Homolium...".

38 For example, WACE (1906); BAKHUIZEN (1992); InTZESILOGLOU (1994), p. 31-56; HeLly (2004), p. 101-124; HeLly (2006), p. 145-169.

39 Batziou-Efstathiou (2002).

40 Strabo, IX, 5, 15.

41 Cf. Intzesiloglou (1996), p. 91-109; on komai in Macedonia, Hatzopoulos (1996), p. 120-121.

42 Hansen (2004), p. 115-119; Reger (2004), p. 145-180.

${ }^{43}$ Cf. KRAVARITOU (forthcoming).
} 
synoecism. In addition, even for the securely identified polis of Demetrias itself there are significant problems regarding the identification and the attribution of its cult places. Firstly, the diachronic and continuous habitation in the small plain of the head of the Pagasetic Gulf made the transportation and re-use of its stone material an extremely widespread practice; consequently, epigraphic material related to cults is usually found out of context. ${ }^{44}$ Secondly, the votive landscape is shrouded in mist, since most of the material remains unpublished, thus undated and even currently unidentifiable. ${ }^{45}$

\section{1. ... the Thessalian background}

A first overview of the archaeological evidence related to settlement ruins that were brought to light in the area of the future polis of Demetrias strongly indicates that at the end of the fourth/beginning of the third century BC almost all settlements and their cult places are abandoned. On the SW edge of the inlet, the suburban sanctuary, along with the archaic and classical city located on the hill Soros (ancient Amphanai? Pagasai?), contain no finds postdating the early third century. Fourth-century artefacts were found scattered in the sanctuary's pronaos and the two lateral rooms, both closed permanently ever since (Table 1, 2-3). This sanctuary has been tentatively attributed to Apollo (Pagasaios?) (Table 1, 1 and 5-6); fourth-century coins issued by Pagasai bear the head of the poliadic divinity Apollo Pagasaios (Table 1, 4). Furthermore, on the western part of the inlet, the remains of a Doric temple that is situated under the modern church of Ag. Theodoroi (Table 1, 12-14) on the hill Palia/Kastro of Volos, has been attributed to Artemis Iolkia, the poliadic divinity depicted on the fourth-century coins of classical Iolkos (Table 1, 15). The city has been tentatively identified with the Classical deposits at Palia that can be associated with contemporary graves of the neighboring cemetery at Nea Ionia. ${ }^{46}$ The Geometric and Classical finds discovered within the ruins of the temple combined with the lack of posterior evidence suggest the abandonment of both sanctuary and settlement in the early third century. Furthermore, on the NE edge of the inlet, the late Classical/early Hellenistic fortified settlement on the hill of Goritsa (ancient Methone?), where a cave dedicated to Zeus Meilichios has been excavated (Table 1, 44), was also abandoned at the same time. ${ }^{47}$ Finally, besides the ruins on the hill Soros, two more sites with classical deposits have been put forward as Pagasai. They are both situated beneath later Demetrias, ${ }^{48}$ thus, their stone material was either destroyed or re-used and consequently the

\footnotetext{
${ }^{44}$ IG IX 2, 1101; 1107a-b (found $20 \mathrm{~km}$ from Demetrias).

45 Cf. Stamatopoulou (2004-2009).

46 Malakasioti (1998), p. 419-422.

47 BAKHuizen (1992); $c$. Helly (2006).

48 STÄhlin, MeYer, Heidner (1934).
} 
identification of cult places is seriously obstructed. However, traces of two sanctuaries that seem to antedate the synoecism were excavated in the area, by Arvanitopoulos, and were attributed to Herakles and Hera respectively (Table 1, 25 and 28). Also, traces of an altar/exedra(?) to a prothyraia divinity - probably Ennodia, the great Pheraian Goddess - was located on the main road leading from Pagasai to Pherai (Table 1, 23); also, a votive stele to Ennodia Patroa belongs to the same classical deposits beneath Demetrias (Table 1, 24). Pherai's presence on the inlet had surely influenced the local cult landscape; Theopompus mentions the cult of Dionysus Pelekys at Pagasai (Table 1, 22), with strong relations to Pherai, while Hermes Chthonios (Table 1, 30), the prominent Thessalian divinity, is depicted on funerary monuments and connected with the afterlife voyage of the dead ${ }^{49}$.

In addition, an archaic and classical sanctuary was recently discovered at the locality Spartias, situated also along the classical road between Pherai and Pagasai; a votive inscription to Herakles, a divinity strongly related to the fifth century foundation myths of Pherai, was uncovered from the ruins (Table 1, 2627). This critical road of communication ${ }^{50}$, exchange and commercial activities between inner Thessaly and the Aegean would have hosted more peri-urban and rural sanctuaries, whose fate might have been modified after the enactment of the border polity between Demetrias and Pherai by Demetrius; in the absence of excavated material, this issue remains subject to future investigation.

Furthermore, outside the area of the inlet of the Gulf, an early sanctuary dedicated to Zeus Akraios and most probably a cave of Chiron were unearthed on the summit of Mount Pelion (Table 1, 42-43), as well as an archaic and a classical layer of the sanctuary of Apollo Koropaios at modern Korope (Ancient Korope?) (Table 1, 7-10). As far as the rest of the peninsula is concerned, due to the absence of systematic excavations most of the settlements - whose presence is attested in the ancient sources- are not yet located or securely identified. ${ }^{51}$ Consequently, eventual population transfer from this area or cult relocation in terms of the synoecism cannot be identified for the moment. A classical sanctuary - Artemis Tisaia (?) - has been partially uncovered at Theotokou (Table 1, 16-18), while a strong presence of heroic and other poliadic cults is indicated by fourth-century coins issued by the Magnesian communities, which bear representations of them (Table 1, 11, 20-21, 32-33, 41).

To sum up, since the early settlements in the area of the future polis of Demetrias - except of that/those beneath its ruins - were abandoned at the beginning of the third century, we conclude that Demetrius' synoecism might have involved - at least for the area of the inlet of the Gulf - physical

\footnotetext{
49 Avagianou (2002).

50 Arvanitopoulos (1911a), p. 301-303.

51 For ex. Meliboia; $c f$. TZiaphalias, IntZesiloglou, Helly (2010).
} 
synoecism and population transfer, implying also the abandonment of the old agoras and main cult places and, thus, a total "rethinking" of the region's sacred space. Most of the cults attested in the area of the future polis of Demetrias Apollo(?) of Soros and Korope, Ennodia, Heracles and surely Hermes Chthonios - should be assigned to the "proper Thessalian background" that according to Helly - predate non only the synoecism but also the installation of the Magnetes on the southern part of Pelion and the bay in the fourth century. ${ }^{52}$ Is there any visible impact of this cultic background on the restructuring of religious life within the synoecism of Demetrias?

\section{2. ... cultic background and royal foundation}

Although archaeological research in the polis of Demetrias is ongoing and the entire city has not yet been investigated, there is important evidence implying a certain degree of re-appraisal of local traditional religious patterns, which have actually found a place, after 293, in the urban tissue and the newly established religious landscape of the royal foundation.

The figure of Hermes Chthonios, the most prominent divinity of the "proper Thessalian background", which was associated with post-mortem popular beliefs, is still present; surprisingly, he is depicted in almost all funerary stelai of Demetrias beside or below the painted scene with the deceased (Table 2, 44). In a new funerary context characterized by the multicultural identity of the dead and where the typology of the stelai is not of Thessalian origin, Hermes Chthonios, slightly modified, finds his place as a painted herm, while his name is never written on the stelai. $^{.53}$

Furthermore, two more cults of the Thessalian sub-stratum were adapted in Demetrias. The Pheraian Goddess Ennodia, along with Artemis Ennodia and Ennodia Hecate (Table 2, 11-12, 37), are amalgamated with new feminine Hellenistic deities, like Pasikrata and the Mother of the Gods (Table 2, 29, 31, 50) 54 Also, there are traces of Heracles' cult (Table 2, 40).

In addition, a temple of Artemis Iolkia, the poliadic divinity of Iolkos, in the agora of the new polis adjacent to the palace attests that this early prominent cult was relocated in the new city (Table 2, 13). The popularity of the Iolkian Artemis, praised by the contemporary Apollonius of Rhodes ${ }^{55}$ and represented on third-century coins issued by Demetrius (Table 2, 14), made it an ideal vehicle for promoting the new polis identity and the naval plans of Demetrias,

\footnotetext{
52 Helly (2006), p. 146-163.

53 Wolters (1975), p. 86-87, n. 5 ; STAMATOPOUlOU (1999), p. 153-162.

54 Chrysostomou (1998), p. 187-230.

55 Apollonius of Rhodes, Argonantica I, 570-572; III, 312.
} 
by forging a bond with the remote Greek legendary past: the panhellenic nautical expedition of the Argonauts.

Finally, archaeological evidence suggests that the sanctuary of Zeus Akraios and Chiron on the summit of Mount Pelion (Table 2, 58, 60) and the oracular sanctuary of Apollo Koropaios at Korope (Table 2, 4-6) continued to exist throughout the Hellenistic period until late antiquity, as extra-urban sanctuaries of Demetrias. The city organised yearly processions to them during the festival days of the Gods; foreigners are also attested as visitors of the famous oracle of Apollo at Korope. ${ }^{56}$

\subsection{New Cults and royal foundation}

Although the aforementioned evidence clearly indicates the continuation of cults from the early religious sub-stratum of the region into the new city, we should not forget that Demetrias was a Macedonian city and basileion, ${ }^{57}$ founded to serve as royal residence from its creation until the decline of the Macedonian presence in the region and the advent of the Romans in 168. Thus, we would normally expect traces of the Macedonian presence on a cultic level.

An edict of Philip $\mathrm{V}$ attests the existence of the cult of Heracles Kynagidas, with parallels in Macedonia relating to local social institutions (Table 2, 43); kynegoi, according to Hatzopoulos, were the royal ephebes in charge of the forests and the royal hunts. ${ }^{58}$ Thus, this cult conforms to the presence of the basileion and the basilike chora, in Demetrias. ${ }^{59}$

Furthermore, an amalgamation of old and new motifs, in order to construct a new religious and political identity in the newly founded Demetrias, is perfectly attested by two third-century resolutions from Iolkos and Glaphyrai, mentioning the presence of a new common cult of the archegetai kai ktistai (Table $2,8)$ into Demetrias and its chora, as well as of an archegeteion - the official cult seat. Marzolff identified it with the so-called "heroon/mausoleum" of Demetrius, an important building with fine sculpted architectural decoration of Ionic style, located at a prominent position above the theatre within the walls of Demetrias (Table 2, 9). However, the lack of epigraphic corroboration and the fact that it was left unfinished allow for the moment only speculation regarding its character. The presence of the archegeteion in Demetrias, along with eventual celebrations commemorating the synoecism's foundation, are perfectly justified by the politics of the synoecism (cf. the Synoikia in Athens), although this does not exclude the possibility of cult celebration on the minor synoecized

\footnotetext{
56 IG IX 2, 1109a.

57 Strabo, IX, 4, 15.

58 Hatzopoulos (1994), p. 102-111.

${ }^{59}$ Batziou-Efstathiou and Pikoulas (2006), p. 79-89.
} 
communities. Obviously, the heroic cults of these former poleis commemorating the progenitors of their proper genealogy were now replaced by this new common cult in honour of old heroes and new royal founders of Demetrias.

The ruler's cult, being the best mode of post-classical religious expression among Greek communities, has surely left important traces on Demetrias' ritual landscape. Thus, the cult scene described by the Glaphyrai degree delivers a prestigious ritual performed by more than one priests and a board of magistrates. ${ }^{60}$ However, the opisthographic degree of the demos of Iolkos, dated to the reign of Antigonus, claims restoration of the local heroes' cults, ${ }^{61}$ and it was generally considered as proof of the local discontentment towards the Macedonian domination. As I have recently argued elsewhere, ${ }^{62}$ this hypothesis seems unlikely because it opposes the general structure and the language of the inscription, which attests Hellenistic negotiation patterns between poleis and Macedonian kings. Side A follows the energetism model, praising the kings for their goodwill towards Iolkos' ancestral cults, while side B negotiates with them - obviously during an internal lack of 'resources' - the financing of local rituals traditionally untertaken by the demos itself. Furthermore, as I have also proposed, ${ }^{63}$ in the time of the Iolkos inscription this royal cult included the two Macedonian kings, Antigonus and Demetrius together. This is indicated by the fact that both kings are praised together in the honorary decree of side A, while side B relates to the sacrifices for the 'archegetai and ktistai'. Also the term ktistai is used in plural form indicating cult for more than one founder; finally, although Demetrius Poliorketes founded the synoecism of Demetrias, the study of the urban development of the city indicated that the long peaceful reign of Antigonos Gonatas was instrumental for the dynamic development of the city and its public and private sectors. In this respect, it would be appropriate for Demetrias to bestow honours upon both kings. Moreover, almost fifty years later, a statue base for Antigonus Doson and Philip V attests the dynamic development of the royal cult in Demetrias (Table 2, 1).

Furthermore, the royal polity over the annual religious year of Demetrias included reform of the calendar month names. A new calendar with twelve months named after the twelve Gods, known also from other Macedonian

${ }^{60}$ IG IX 2, 1099a, 1. 1-11: “. . . [the performance of the sacrifice] . . the magistr[a]tes must provide for . . . the [ex]pense [for] the [o]x must be [p]aid by th[e] $\operatorname{tr}[\mathrm{ea}]$ surer [and] by hi[m] who is in [charge] of [ .....] [and] [th]e sacrifice [must be placed under the supervision of the priests and of those being at the public records, while the magistrates will be in charge of th[e] banquet" (Translation: author).

61 MEYER (1936), 1. B1-6: "Since, the common [sacrifices for the archegetai and ktistai] are limited, [and no other] sacrifices are performed, [the demos of the Iolkians] shall sacrifice according to the ancestral customs, [to the arche]getai and ktistai [of the demos, so as not to be, from them, any] wrath [towards the city for neglecting] the heroes, ..." (Translation: author)

62 KRAVARITOU (forthcoming)

63 Ibid. 
royal foundations, was introduced in Demetrias. ${ }^{64}$ Hatzopoulos assigned it to the Platonic influence exercised in the Macedonian court. ${ }^{65}$ Since month names relate to festivals in honor of divinities acting in the local legendary past, calendars were always a vehicle of historical remembrance and collective identity; thus, by introducing theophoric month names, the normal course of local collective memory was strongly deviated.

Also, more innovations in cultic life are also attested. A sanctuary excavated by Arvanitopoulos in the eastern sector of the city was identified with the Thesmophorion, mainly due to a third-century inscription attesting repair-work "on the sanctuary of Demeter, Kore and Plouton, where the Thesmophorion stood in the past" (Table 2, 32). Also, votive deposits outside the southern gates of the polis' fortification attest to the presence of the cult of Pasikrata, related to Artemis Hecate, Ennodia and Aphrodite (Table 2, 50-51). All these feminine deities share an abundant votive record that is currently, in its major part, unpublished. Future studies will demonstrate if eventually some of these votive objects were dedicated to those divinities in order to commemorate the end of the period of girls' service in the sanctuaries of feminine deities', as it happens with their counterparts in Macedonia and even elsewhere in Thessaly, already from the Classical period. ${ }^{60}$

\subsection{Foreign cults}

Close to the Thesmophorion stands another building tentatively identified with the Metroon of the city, the official cult seat of the Phrygian goddess Cybele (Table 2, 29-30), while Arvanitopoulos reports the presence of a 'small temple of Cybele' at Pagasai (Table 2, 31).67 Also, the cosmopolitan landscape of Demetrias hosted many Egyptian divinities; their official cult seat, the Serapieion, is currently unlocated (Table 2, 49, 54-56).68 Their cults survived down to the Roman period. The presence of an Egyptian priest of Isis and a Phoenician one (Table 2, 36, 47) indicate that - in a multicultural political environment - priesthood in foreign cults was equally undertaken by foreigners. In addition, in Roman times, there is evidence for the cult of the Syrian goddess Atargatis (Table 2, 25), while A. Arvanitopoulos reported also an intramuros sanctuary of Harpokrates (Table 2, 38).

\footnotetext{
64 TRÜMPY (1997), p. 266-267.

${ }^{65}$ Hatzopoulos (1996), p. 163-164.

${ }^{66}$ Cf. Hatzopoulos (2006), p. 54-55.

${ }^{67}$ Arvanitopoulos (1916), p. 31.

${ }^{68}$ Decourt, TZiafalias (2007).
} 


\section{The Magnesian Koinon: cults and politics}

After the Flamininian intervention in the Greek affairs, Macedonians left Demetrias which received a Roman garrison until 191, when the city became the capital of the first Magnesian Koinon. Macedonians returned briefly in 191, before releasing permanent control to the second Koinon and to the Romans, after the battle of Pydna. ${ }^{69}$ Thus, after the Macedonians, the political landscape is reformed once again, since independent communities, called poleis, as well as various demotic names, ${ }^{70}$ are now epigraphically attested. Naturally, another restructuring of the religious life followed the new socio-political landscape.

Besides the cults of foreign divinities that survived down to the Roman period (Table 2, 56), old Poliadic cults (Aphrodite Neleia, Artemis Pagaseitis, etc.) revive in a nostalgic atmosphere for the traditional cults of the region (Table 2, 2-3, 7, 17). In that context, the old Artemis Iolkia, Zeus Akraios and Apollon Koropaios now become the tutelary deities of the Koinon (Table 2, 6, 15-16, 59-60), while Zeus Akraios, Chiron and the Argo-ship are depicted on its coins (Table 2, 27, 61). Priestly authorities of the tutelary cults are seated in Demetrias, while yearly processions to the extra-urban sanctuaries of Akraios and Koropaios at the extremities of the chora of Demetrias, point to the necessity for symbolic demarcation of the limitrophe areas, just before the final decline and dwindling of the polis.

Furthermore, during the $1^{\text {st }}$ cent., the cult of the ruling powers in Demetrias finds other destinators: the powerful and divine Roman emperors, who - besides the old poliadic deities - receive the interest and the honours of the Magnesian Koinon (Table 2, 64-72). "Gaius Julius Cesar Emperor God" and "God, son of God, Titus Cesar, New Apollo, Benefactor" are some of the Emperors who joined the divine sphere and received honors in Demetrias. A votive inscription to the "Olympian Gods and Major Savior Emperor Lucius Septimus Sevirus Pertinakis" testifies the inclusion of the imperial cult in the sphere of the cult of the Olympian Gods. Honorific statues and votive inscriptions were also erected in honor of other emperors, who probably enjoyed themselves the same divine status, at least until the coming of the Christian God.

\section{Conclusion}

This preliminary study of the religious interface of Hellenistic Demetrias strongly indicates re-organization of the local cult activities after the establishment of the local synoecism. The inevitable presence of Macedonian cults -

${ }^{69}$ INTZESILOGLOU (1996).

70 IG IX.2 1101; 1102; 1103; IG IX.2 1108; 1133; SEG 12, 306 (poleis). SEG 3, 405; IG IX.2 1109, 1. 2-8; SEG XXXIV 553 (demotika: Iolkios, Glaphyreus, Spalathreus, Aeoleus, Pagasites, Koropaios, Demetrieus). 
including cult of the ruling powers - seals the political identity of this basileion, which in addition used a new calendar of month-names, proper to other royal foundations. However, an overview of the available archaeological evidence demonstrates that at least some of the cults of the old local "Thessalian backround" were incorporated into the new polis. In detail, the presence of the prominent Iolkian Artemis in the agora of Demetrias suggests a certain reappraisal of old motifs by the polis royal administration. Also, the presence of Hermes Chthonios on the funerary stelai attests that this re-appraisal operated also on a wide popular basis; and, surely, on a multicultural one, ${ }^{71}$ since Hermes is depicted on funerary stelai belonging also to foreigners. ${ }^{72}$ This fact, along with the presence of the organised cult of foreign deities, point out that, besides a synoecism of old Thessalian communities and a Macedonian seat, Demetrias was during the Hellenistic period a cosmopolitan city and an international harbor. In Roman times, the emotional bewilderment of Greek reality in front of new political powers reflects on the religious attitude of the Magnesian Koinon, wavering between traditional deities and divinized Emperors.

Archaeological Institute for Thessalian Studies

Sofia KRAVARITOU

Gamveta, 74-76

GR - 38221 VOLOS

E-mail:skravariton@gmail.com

${ }^{71}$ On multiculturalism and the sacred space in Demetrias, see KRAVARITOU (in preparation).

72 Personal communication with Maria Stamatopoulou; $c f$. STAMATOPOULOU (in preparation). 


\section{Catalogue of Cults}

\section{Table 1. Archaic-Classical period}

\begin{tabular}{|c|c|c|c|c|}
\hline & Cult & Evidence & Date & Site \\
\hline 1. & Apollo Pagasaios ${ }^{73}$ & Altar & Archaic & Pagasai \\
\hline 2. & $\begin{array}{l}\text { Apollo } \\
\text { Pagasaios?74 }\end{array}$ & $\begin{array}{l}\text { Suburban sanctuary. } \\
\text { Votive objects }\end{array}$ & Archaic & $\begin{array}{l}\text { Soros (ancient } \\
\text { Amphanai? Pagasai?) }\end{array}$ \\
\hline 3. & $i d .75$ & $i d$. & Classical & $i d$. \\
\hline 4. & Apollo Pagasaios ${ }^{76}$ & Coins & $4^{\text {th }}$ cent. & $\begin{array}{l}\text { Pagasai (legend } \\
П А Г A \Sigma A I \Omega N \text { ) }\end{array}$ \\
\hline 5. & Apollo?77 & Votive column & $5^{\text {th }}$ cent. & $i d$. \\
\hline 6. & Apollo 78 & Votive base & $4^{\text {th }}$ cent. & $i d$. \\
\hline 7. & $\begin{array}{l}\text { Apollo } \\
\text { Koropaios?79 }\end{array}$ & $\begin{array}{l}\text { Architectural } \\
\text { material }\end{array}$ & Archaic & $\begin{array}{l}\text { Korope (ancient } \\
\text { Korope?) }\end{array}$ \\
\hline 8. & $i d^{80}$ & "Sacred law" & $6^{\text {th }}$ cent. & $i d$. \\
\hline 9. & $\begin{array}{l}\text { Apollo } \\
\text { Koropaios }^{81}\end{array}$ & $\begin{array}{l}\text { Architectural } \\
\text { material and finds }\end{array}$ & Classical & $i d$. \\
\hline 10. & $i d .82$ & "Sacred law" & $5^{\text {th }}$ cent. & $i d$. \\
\hline 11. & Artemis $^{83}$ & Head on coins & $i d$. & Rhizous \\
\hline 12. & Artemis Iolkia?84 & Sanctuary & Geometric & $\begin{array}{l}\text { Palia/Kastro of Volos } \\
\text { (ancient Iolkos?) }\end{array}$ \\
\hline 13. & $i d$. & $i d$. & Archaic & $i d$. \\
\hline 14. & $i d$. & $i d$. & Classical & $i d$. \\
\hline 15. & Artemis Iolkia ${ }^{85}$ & $\begin{array}{l}\text { Head of Artemis on } \\
\text { coins }\end{array}$ & $4^{\text {th }}$ cent. & $\begin{array}{l}\text { Iolkos (legend } \\
\text { I } \Omega \Lambda \mathrm{KE} \Omega \mathrm{N} \text { ) }\end{array}$ \\
\hline
\end{tabular}

${ }^{73}$ Hesiod, Aspis, 70.

74 MaZarakis (2009), p. 278; (2011), p. 148-167.

75 MAZARAKIS (2009), p. 273-278; ibid.

${ }^{76}$ LiAMPI (2005), p. 30-35, plate 3 (3).

${ }_{77}$ Milojcic (1974), p. 74. Cf. Mazarakis (2009), p. 273, n. 33.

78 MilOjCIC (1974), p. 65.

79 PApachatzis (1960), fig. 6.

${ }^{80}$ IG IX 2, 1202.

81 PAPACHATZis (1960), p. 4-14.

82 IG IX 2, 1203.

83 Rogers (1932), 535-536. Helly (2004), pl. 3, 19-21.

84 Arvanitopoulos (1909a), p. 157-158.

${ }^{85}$ LiAmPI (2005), p. 23-30, pl. 3 (1-2). 


\begin{tabular}{|c|c|c|c|c|}
\hline 16. & Artemis Tisaia?86 & $\begin{array}{l}\text { Poros architectural } \\
\text { material } \\
\text { and finds }\end{array}$ & Archaic & $\begin{array}{l}\text { Near Palaiokastro at } \\
\text { Theotokou (ancient } \\
\text { Sepias?) }\end{array}$ \\
\hline 17. & $i d$. & $i d$. & Classical & $i d$ \\
\hline 18. & Artemis Tisaia ${ }^{87}$ & Temple & Roman reference & $\begin{array}{l}\text { Coastal Pelion, } \\
\text { opposite Skiathos }\end{array}$ \\
\hline 19. & Asclepios ${ }^{88}$ & Stone relief & Classical? & $\begin{array}{l}\text { Palaiokastro at } \\
\text { Theotokou (Ancient } \\
\text { Sepias?) }\end{array}$ \\
\hline 20. & Dionysos ${ }^{89}$ & Coins & $400-344$ & Meliboia \\
\hline 21. & $i d .90$ & $i d$. & $i d$. & Eyrymenai \\
\hline 22. & Dionysos Pelekys ${ }^{91}$ & Festival & 4th cent. & Pagasai \\
\hline 23. & $\begin{array}{l}\text { Ennodia / } \\
\text { prothyraia } \\
\text { divinity?92 }\end{array}$ & $\begin{array}{l}\text { Altar? Exedra? } \\
\text { Cavities for stelais } \\
\text { bases }\end{array}$ & Classical & $\begin{array}{l}\text { Bourboulithra, on } \\
\text { the road to Pherai }\end{array}$ \\
\hline 24. & Ennodia Patroa ${ }^{93}$ & $\begin{array}{l}\text { Stone stele with } \\
\text { votive inscription }\end{array}$ & $4^{\text {th }}$ cent. & $\begin{array}{l}\text { Beneath Demetrias } \\
\text { (Ancient Pagasai?) }\end{array}$ \\
\hline 25. & Hera $^{94}$ & Boundary stele & Archaic & $\begin{array}{l}\text { Aibaliotika (ancient } \\
\text { Pagasai?) }\end{array}$ \\
\hline 26. & Heracles 95 & $\begin{array}{l}\text { Architectural } \\
\text { material (altar) and } \\
\text { votive deposits }\end{array}$ & $i d$. & $\begin{array}{l}\text { Spartias (on the } \\
\text { ancient road to } \\
\text { Pherai) }\end{array}$ \\
\hline 27. & $i d$. & $i d$. & Classical & $i d$. \\
\hline 28. & Heracles?96 & Shrine and finds & $4^{\text {th }} / 3^{\text {td }}$ cent. & $\begin{array}{l}\text { North of Demetrias' } \\
\text { theater }\end{array}$ \\
\hline 29. & Hermes $^{97}$ & Votive base & $5^{\text {th }}$ cent. & $\begin{array}{l}\text { Soros' region } \\
\text { (Ancient Amphanai?) }\end{array}$ \\
\hline 30. & Hermes Chthonios ${ }^{98}$ & Funerary stele & Late Classical / & Beneath Demetrias \\
\hline
\end{tabular}

86 Wace, Droop (1906-1907). Adrimi-Sismani (1996).

87 Valerius Flaccus, Argonantica II, 7.

${ }^{88}$ LiAPIS (2004), p. 96.

89 Rogers (1932), 389. Helly (2004), pl. 3, 17.

${ }^{90}$ Rogers (1932), 212-213. Helly (2004), pl. 3, 23-24.

91 Theopompus in Scholia in Hom. Il. XXIV, 428.

92 Arvanitopoulos (1915), p. 182-183

${ }^{93}$ IG IX 2, 358.

94 Arvanitopoulos (1915), p. 159.

95 Arvanitopoulos (1911a), p. 300-301; InTZesiloglou (1999), p. 405; also in Ethnos, 7.9. 2007.

96 Arvanitopoulos (1915), p. 161-162.

${ }^{97}$ Arvanitopoulos (1909a), p. 164.

98 Arvanitopoulos (1909b), p. 364. 


\begin{tabular}{|c|c|c|c|c|}
\hline & & & Early Hellenistic & (Classical Pagasai?) \\
\hline 31. & Nymphs 99 & $\begin{array}{l}\text { Votive stelai, pottery, } \\
\text { terracotta figurines, } \\
\text { bronze jewellery }\end{array}$ & $\begin{array}{l}\text { Late Classical / } \\
\text { Early Hellenistic }\end{array}$ & Mount Ossa \\
\hline 32. & $\begin{array}{l}\text { Nymphs or } \\
\text { Maenads }{ }^{100}\end{array}$ & Coins & $400-344$ & Eyreai and Meliboia \\
\hline 33. & Philoctetes $^{101}$ & $\begin{array}{l}\text { Head of Ph. depicted } \\
\text { on coins }\end{array}$ & 350 or earlier & Homolion \\
\hline 34. & Poseidon?102 & Votive & $5^{\text {th }}$ cent. & $\begin{array}{l}\text { Soros (ancient } \\
\text { Amphanai? Pagasai?) }\end{array}$ \\
\hline 35. & $i d .^{103}$ & Votive stele & $5^{\text {th }}$ cent. & $\begin{array}{l}\text { Aligarorema (ancient } \\
\text { Pagasai?) }\end{array}$ \\
\hline 36. & $i d .^{104}$ & $i d$ & $i d$ & $\begin{array}{l}\text { Walled in the } \\
\text { Monastery of Saint } \\
\text { Demetrius (Stomion. } \\
\text { Mount Ossa) }\end{array}$ \\
\hline 37. & Themis ${ }^{105}$ & Sacred property & Classical & $\begin{array}{l}\text { Kokkino Nero } \\
\text { (ancient Eyrymenai?) }\end{array}$ \\
\hline 38. & Themis Agoraia106 & Votive stele & $i d$. & $\begin{array}{l}\text { Chorto (ancient } \\
\text { Spalauthra?) }\end{array}$ \\
\hline 39. & Twelve Gods ${ }^{107}$ & $\begin{array}{l}\text { Marble Dodekatheon } \\
\text { (Apollo, Poseidon } \\
\text { and Athena) }\end{array}$ & $5^{\text {th }}$ cent. & $\begin{array}{l}\text { Polydendri (ancient } \\
\text { Meliboia? Eureai?) }\end{array}$ \\
\hline 40. & Zeus $^{108}$ & Temple and pottery & Classical & $\begin{array}{l}\text { Laspochori on } \\
\text { Mount Ossa (ancient } \\
\text { Homolion? } \\
\text { Eyrymenai?) }\end{array}$ \\
\hline 41. & $i d .109$ & Coins & $4^{\text {th }}$ cent. & Rhizous \\
\hline 42. & Zeus Akraios ${ }^{110}$ & $\begin{array}{l}\text { Sanctuary, } \\
\text { inscriptions, pottery, } \\
\text { finds }\end{array}$ & Classical & $\begin{array}{l}\text { Summit of Mount } \\
\text { Pelion }\end{array}$ \\
\hline
\end{tabular}

\footnotetext{
99 Arvanitopoulos (1911a), p. 284-285.

100 Rogers (1932), 210, 211a, 391-393. Helly 2004, pl. 1-2.

101 Rogers (1932), 257-260. Helly (2004), pl. 4.

102 Cf. l.c. (n. 73).

103 Giannopoulos (1933), p. 4, 12.

104 INTZESILOGLOU (2000), tabl. 80-81.

105 SEG 37, 491

106 Arvanitopoulos (1909b), p. 300-301.

107 Giannopoulos (1932), p. 19, 2-4

108 Arvanitopoulos (1911a), p. 284-285.

109 Rogers (1932), nos. 357-358; Helly (2004), pl. 3, 18.

110 Arvanitopoulos (1911a), p. 305-315.
} 


\begin{tabular}{|c|l|l|l|l|}
\hline 43. & $\begin{array}{l}\text { Zeus Akraios and } \\
\text { Chiron }^{111}\end{array}$ & $\begin{array}{l}\text { Sanctuary, } \\
\text { precinct/cave }\end{array}$ & $4^{\text {th }}$ cent. & id. \\
\hline 44 & Zeus Milichios 112 & $\begin{array}{l}\text { Cave.Votive } \\
\text { inscription }\end{array}$ & $4^{\text {th }} / 3^{\text {td }}$ cent. & $\begin{array}{l}\text { Goritsa (Ancient } \\
\text { Methone?) }\end{array}$ \\
\hline 45. & & "Sacred law"113 & $5^{\text {th }}$ cent. & $\begin{array}{l}\text { Palaiotrikery } \\
\text { (Ancient } \\
\text { Kikynethos) }\end{array}$ \\
\hline
\end{tabular}

\section{Table 2. Hellenistic-Roman period}

\begin{tabular}{|c|c|c|c|c|}
\hline & Cult & Evidence & Date & Site \\
\hline 1. & $\begin{array}{l}\text { Antigonus Doson } \\
\text { and Philip V114 }\end{array}$ & Votive base & $227-221$ & Demetrias \\
\hline 2. & Aphrodite Neleia ${ }^{115}$ & Votive stele (priestess) & $2^{\text {nd }}$ cent. & $i d$. \\
\hline 3. & Aphrodite Neleia ${ }^{116}$ & $\begin{array}{l}\text { Coins of the } \\
\text { Magnesian Koinon }\end{array}$ & Imperial & $i d$. \\
\hline 4. & $\begin{array}{l}\text { Apollo } \\
\text { Koropaios?117 }\end{array}$ & $\begin{array}{l}\text { Finds nearby archaic } \\
\text { architectural elements }\end{array}$ & Hellenistic & $\begin{array}{l}\text { Korope (Ancient } \\
\text { Korope ?) }\end{array}$ \\
\hline 5. & $\begin{array}{l}\text { Apollo } \\
\text { Koropaios }^{118}\end{array}$ & $\begin{array}{l}\text { Decree on the } \\
\text { function of the oracle }\end{array}$ & $2^{\text {nd }}$ cent. & $i d$. \\
\hline 6. & $i d .119$ & Public decrees & $2^{\text {nd }}$ cent. & Demetrias \\
\hline 7. & $\begin{array}{l}\text { Apollo } \\
\text { Koropeites }^{120}\end{array}$ & Votive stele & Roman & $\begin{array}{l}\text { Korope (Ancient } \\
\text { Korope?) }\end{array}$ \\
\hline 8. & $\begin{array}{l}\text { Archegetai and } \\
\text { ketistai } 121\end{array}$ & Public resolutions & $3^{\text {td }}$ cent. & $\begin{array}{l}\text { Iolkos, Glaphyrai? } \\
\text { (komai(?) of } \\
\text { Demetrias) }\end{array}$ \\
\hline 9. & $i d .122$ & Heroon/Mausoleum? & $4^{\text {th }} / 3^{\text {td }}$ cent.? & Demetrias. Hill 84 \\
\hline 10. & Artemis ${ }^{123}$ & Marble statuettes & Hellenistic & Museum of Volos \\
\hline
\end{tabular}

\footnotetext{
111 Herakleides, in Pseudo-Dichaearchus 2,8 (GGM I, 107, ed. MÜLLER).

112 SEG 41, 533.

113 IG IX 2, 1222.

114 SEG 22, 308.

115 IG IX 2, 1125.

116 WACE (1906), p. 168.

117 Papachatzis (1960), p. 3-24

118 IG IX 2, 1109a

119 IG IX 2, 1110; 1202.

${ }^{120}$ IG IX 2, 1204

${ }^{121}$ IG IX 2, 1099 a-c. MEYER (1936), p. 367-376.

122 MarzolfF (1987), p. 1-47.
} 


\begin{tabular}{|c|c|c|c|c|}
\hline 11. & Artemis Ennodia ${ }^{124}$ & $i d$ & $i d$ & Demetrias \\
\hline 12. & Artemis Ennodia ${ }^{125}$ & $\begin{array}{l}\text { Stone altar with votive } \\
\text { inscription }\end{array}$ & $i d$. & $i d$. \\
\hline 13. & Artemis Iolkia 126 & Temple & $i d$ & Demetrias. Agora. \\
\hline 14. & $i d .127$ & Head on coins & $3^{\text {rd }}$ cent. & $\begin{array}{l}\text { Demetrias (legend } \\
\Delta \text { HMHTPIE } \Omega N \text { ) }\end{array}$ \\
\hline 15. & $i d .128$ & Public decrees & $2^{\text {nd }}$ cent. & $i d$. \\
\hline 16. & $i d .129$ & (Priestess) & $i d$. & $i d$. \\
\hline 17. & Artemis Pagasitis 130 & Votive stele & $i d$. & $i d$. \\
\hline 18. & Artemis Soteira ${ }^{131}$ & $\begin{array}{l}\text { Sanctuary in the agora } \\
\text { of Spalauthra }\end{array}$ & $130-126$ & $\begin{array}{l}\text { Chorto (Ancient } \\
\text { Spalauthra?) }\end{array}$ \\
\hline 19. & Asclepios $^{132}$ & Public decree & Hellenistic & Demetrias \\
\hline 20. & $i d .133$ & Votive stele (priest) & $i d$ & $i d$. \\
\hline 21. & $i d .134$ & Head on coins & $197 / 146$ & $i d$. \\
\hline 22. & $i d .135$ & Small votive altar & Roman & $i d$. \\
\hline 23. & $i d .136$ & $\begin{array}{l}\text { Coins of the } \\
\text { Magnesian Koinon }\end{array}$ & $46-27$ & $i d$. \\
\hline 24. & $\begin{array}{l}\text { Asclepios and } \\
\text { Hygeia }^{137}\end{array}$ & Votive stele & Roman & $i d$. \\
\hline 25. & Atargates ${ }^{138}$ & $\begin{array}{l}\text { Votive relief } \\
\text { (priestess) }\end{array}$ & $\begin{array}{l}3^{\text {td }} / 4^{\text {th }} \text { cent. } \\
\mathrm{AD}\end{array}$ & $i d$. \\
\hline 26. & Athena ${ }^{139}$ & Priestess & Late Hellenistic & $i d$. \\
\hline
\end{tabular}

\footnotetext{
123 Mitropoulou (1992).

124 Chrysostomou (1998), p. 191-192.

125 SEG 48, 658.

126 IG V 2, 367. BATZIOU (2002), p. 29-30.

127 SEAR (1978), p. 201, 207.

128 IG IX.2, 1109.

${ }^{129}$ IG IX 2, 1122.

${ }^{130} I G$ IX 2, 1123

131 IG IX 2, 1111

132 IG IX 2, 1126

133 Theocharis, ChOurmouziadis (1968), p. 269.

134 Rogers (1932), 354, fig. 177-178.

135 Mitropoulou (1994), 488, fig. 2.

136 Rogers (1932), no. 355a-b, fig. 180.

${ }^{137}$ IG IX 2, 1124

138 SEG 26, 646.

139 SEG 37, 461.
} 


\begin{tabular}{|c|c|c|c|c|}
\hline & & & / Early Roman & \\
\hline 27. & Chiron $^{140}$ & $\begin{array}{l}\text { Coin of the } \\
\text { Magnesian Koinon }\end{array}$ & 196-194 & $i d$. \\
\hline 28. & $\begin{array}{l}\text { Chiron and Zeus } \\
\text { Akraios }^{141}\end{array}$ & $\begin{array}{l}\text { Cave of Chiron and } \\
\text { sanctuary of Zeus } \\
\text { Akraios }\end{array}$ & $3^{\text {td }}$ cent. & $\begin{array}{l}\text { Summit of Mount } \\
\text { Pelion }\end{array}$ \\
\hline 29. & Cybele? ${ }^{142}$ & Metroon? & $\begin{array}{l}\text { Last quarter of } \\
3^{\text {td }} 1^{\text {st }} \text { quarter } \\
\text { of } 2^{\text {nd }} \text { cent. }\end{array}$ & Demetrias \\
\hline 30. & $\begin{array}{l}\text { Cybele, Aphrodite } \\
\text { Epitragia, Ennodia, } \\
\text { Hecate and Zeus } \\
\text { Milichius }^{143}\end{array}$ & Clay figurines & Hellenistic & $i d$. \\
\hline 31 & Cybele?144 & $\begin{array}{l}\text { 'Small temple' and } \\
\text { clay figurines }\end{array}$ & Hellenistic? & $i d$. \\
\hline 32. & $\begin{array}{l}\text { Demeter, Kore, } \\
\text { Plouton }^{145}\end{array}$ & $\begin{array}{l}\text { Public decree } \\
\text { (Thesmophorion and } \\
\text { temenos of Demeter) }\end{array}$ & Late $3^{\text {rd }}$ cent. & $i d$. \\
\hline 33. & Dionysos 146 & Votive & $3^{\text {rd }}$ cent. & $\begin{array}{l}\text { Kaprena (Ancient } \\
\text { Glaphyrai?) }\end{array}$ \\
\hline 34. & $i d .147$ & $i d$. & Hellenistic? & $\begin{array}{l}\text { Palaiokastro at } \\
\text { Lechonia (Ancient } \\
\text { Methone?) }\end{array}$ \\
\hline 35. & $i d .148$ & Priest & $2^{\text {nd }}$ cent. & $\begin{array}{l}\text { Polydendri } \\
\text { (Ancient Meliboia? } \\
\text { Eureai?) }\end{array}$ \\
\hline 36. & Egyptian divinities & $\begin{array}{l}\text { Funerary stele of priest } \\
\text { Asklapiadas of } \\
\text { Sidon }^{149}\end{array}$ & $3^{\text {td }}$ cent. & Demetrias \\
\hline 37. & $\begin{array}{l}\text { Ennodia? } \\
\text { Hecate? }\end{array}$ & Hekataion & Hellenistic & $i d$. \\
\hline
\end{tabular}

140 Moustaka (1983), no. 20, fig. 6.

${ }^{141}$ Cf. o.c. (n. 107).

142 BATZiOU (2002), p. 30-32, fig. 33-36.

143 Batziou (2002), p. 30-32, fig. 33-36, 38. Hornung-BERTEMes (2007), p. 82-84.

144 Arvanitopoulos (1916), p. 31. This material, still unpublished, has been recently identified at the National Museum of Athens and is under publication by Maria Stamatopoulou, whom I thank for this personal communication.

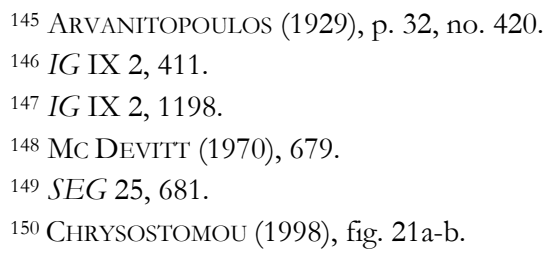




\begin{tabular}{|c|c|c|c|c|}
\hline 38. & Harpocrates?151 & Sanctuary? & Hellenistic & $i d$. \\
\hline 39. & Hera $^{152}$ & Small votive altar & Roman & $i d$. \\
\hline 40. & Heracles $^{153}$ & Votive stele & $3^{\text {rd }} 2^{\text {nd }}$ cent. & $i d$. \\
\hline 41. & $i d .154$ & $i d$. & Hellenistic? & $\begin{array}{l}\text { Chorto (Ancient } \\
\text { Spalauthra?) }\end{array}$ \\
\hline 42. & $i d .155$ & $i d$. & $\begin{array}{l}1^{\text {st }} / 1^{\text {st }} \text { cent. } \\
\mathrm{AD}\end{array}$ & $\begin{array}{l}\text { Palaiokastro of } \\
\text { Argalaste (Ancient } \\
\text { Olizon?) }\end{array}$ \\
\hline 43. & $\begin{array}{l}\text { Heracles } \\
\text { Kynagidas }{ }^{156}\end{array}$ & Edict of Philip V & $221-179$ & Demetrias \\
\hline 44. & $\begin{array}{l}\text { Hermes } \\
\text { Chthonios }{ }^{157}\end{array}$ & $\begin{array}{l}\text { Painted herms on } \\
\text { funerary stelai }\end{array}$ & Hellenistic & Demetrias \\
\hline 45. & Household cults ${ }^{158}$ & $\begin{array}{l}\text { Incense burners, clay } \\
\text { figurines of gods }\end{array}$ & $i d$. & $i d$ \\
\hline 46. & $i d .159$ & $\begin{array}{l}\text { Bronze incense } \\
\text { burners, bronze } \\
\text { figurines of Gods } \\
\text { (Poseidon, Athena, } \\
\text { etc) }\end{array}$ & Roman & $i d$. \\
\hline 47. & Isis $^{160}$ & Priest & $3^{\text {td }}$ cent. & $i d$. \\
\hline 48. & $i d .161$ & Graffito & Hellenistic & $i d$. \\
\hline 49. & $\begin{array}{l}\text { Isis, Serapis, } \\
\text { Anubis }{ }^{162}\end{array}$ & Votive inscription & $i d$. & Pagasai \\
\hline 50. & Pasikrata ${ }^{163}$ & $\begin{array}{l}\text { Votive altars, marble } \\
\text { head, clay figurines, } \\
\text { lamps, etc. }\end{array}$ & $3^{\text {rd }} / 2^{\text {nd }}$ cent. & $\begin{array}{l}\text { Demetrias. Outside } \\
\text { the southern } \\
\text { fortification gate. }\end{array}$ \\
\hline 51. & $i d .164$ & Priestess & $i d$. & Demetrias \\
\hline
\end{tabular}

151 Arvanitopoulos (1915), p. 160-161.

152 Unpublished (Museum of Volos).

${ }^{153}$ IG IX 2, 359a.

${ }^{154}$ IG IX 2, 1210.

155 IG IX 2, 1217.

156 INTZESILOGLOU (2006), p. 67-77.

157 BAtZiou (2002), p. 43, fig. 54-55.

$158 \mathrm{Ibid}$, p. 36.

159 SKafida, Traiantafyllopoulou (forthcoming).

160 STAMATOPOULOU (2008).

161 SEG 43, 525.

162 IG IX 2, 360.

163 SEG 3, 481-2. 


\begin{tabular}{|c|c|c|c|c|}
\hline 52. & Pasikrata ${ }^{165}$ & & Roman & $i d$. \\
\hline 53. & $\begin{array}{l}\text { Private heroiza- } \\
\text { tion }^{166}\end{array}$ & Totenmahl reliefs, etc & Hellenistic & $i d$. \\
\hline 54. & Serapis ${ }^{167}$ & Serapieion & $2^{\text {nd }}$ cent. & $i d$. \\
\hline 55. & $i d .168$ & Priests & $i d$ & Makrynitsa \\
\hline 56. & Sarapis and Isis ${ }^{169}$ & Votive inscription & Roman & Demetrias \\
\hline 57. & Zeus?170 & $\begin{array}{l}\text { Votive relief with } \\
\text { winged thunderbold }\end{array}$ & $\begin{array}{l}\text { Late } \\
\text { Hellenistic? }\end{array}$ & $\begin{array}{l}\text { Chorto (ancient } \\
\text { Spalauthra?) }\end{array}$ \\
\hline 58. & Zeus Akraios ${ }^{171}$ & $\begin{array}{l}\text { Architectural elements } \\
\text { and miscellaneous } \\
\text { finds. }\end{array}$ & Hellenistic & $\begin{array}{l}\text { Summit of Mount } \\
\text { Pelion }\end{array}$ \\
\hline 59. & $i d .172$ & Cult regulation & $2^{\text {nd }} / 1^{\text {st }}$ cent. & $\begin{array}{l}\text { Korope. (Ancient } \\
\text { Korope ?) }\end{array}$ \\
\hline 60. & $i d .173$ & Public decrees (priest) & $2^{\text {nd }}$ cent. & Demetrias \\
\hline 61. & Zeus Akraios ${ }^{174}$ & Head on coins & Imperial & $i d$. \\
\hline 62. & Zeus Milichios ${ }^{175}$ & Votive & $2^{\text {nd }}$ cent. & $i d$. \\
\hline 63. & Zeus Sabazios ${ }^{176}$ & Votive relief & Roman & Trikeri \\
\hline
\end{tabular}

\section{Roman Imperial cult}

\begin{tabular}{|l|l|l|l|l|}
\hline 64. & Julius Cesar $^{177}$ & Honorific statue & 48 & Demetrias \\
\hline 65. & Tiverius $^{178}$ & $i d$. & $1-50 \mathrm{AD}$ & $i d$. \\
\hline 66. & Titus Cesar ${ }^{179}$ & $\begin{array}{l}\text { id. } \text { (honored by the } \\
\text { Magnetes) }\end{array}$ & $71-81 \mathrm{AD}$ & $i d$. \\
\hline
\end{tabular}

\footnotetext{
164 SEG 3, 483.

165 PAPACHATZIS (1958), p. 62.

166 IG IX 2, 1099a; 1168-1170; 1192.

${ }^{167}$ IG IX 2, 1107b; 1101.

168 IG IX 2, 1107b; 1133.

169 MC DEVITT (1970), p. 97, 713.

${ }^{170}$ IG IX 2, 1211.

171 Arvanitopoulos (1911a), p. 305-315.

172 IG IX 2, 1110.

173 IG IX 2 1103; 1105 II; 1108-1110.

174 WACE (1906), p. 155-156, fig. 12.

175 SEG 37, 460.

176 Mitropoulou (1984), p. 93-95, fig. 1.

177 SEG 14, 474.

178 SEG 23, 449.

179 SEG 23, 450.
} 


\begin{tabular}{|l|l|l|l|l|}
\hline 67. & $\begin{array}{l}\text { Olympian Gods and } \\
\text { Lucius Septimus } \\
\text { Sevirus180 }\end{array}$ & Votive altar & $\begin{array}{l}\text { Late 2nd cent. } \\
\text { AD }\end{array}$ & $i d$. \\
\hline 68. & $i d .181$ & Honorific statue & $193-211 \mathrm{AD}$ & $i d$. \\
\hline 69. & $\begin{array}{l}\text { Marcus Aurelius Severus } \\
\text { Antoninus182 }\end{array}$ & $i d$. & $212-217 \mathrm{AD}$ & $i d$. \\
\hline 70. & $\begin{array}{l}\text { "Major and Pius Master } \\
\text { Cesar Marcus Aurelius } \\
\text { Karus"183 }\end{array}$ & $i d$. & $282 \mathrm{AD}$ & $i d$. \\
\hline 71. & $\begin{array}{l}\text { "Emperor ... Pius .... } \\
\text { Sermatikos"184 }\end{array}$ & $i d$. & $308-324 \mathrm{AD}$ & $i d$. \\
\hline 72. & Sebastoi185 & Stele (Priests) & Late Imperial & $i d$. \\
\hline
\end{tabular}

\section{Bibliography}

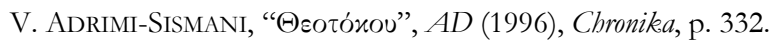

A. Arvanitopoulos, PAE (1909a), p. 157-158.

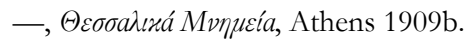

-, PAE (1911a), p. 284-356.

—, "Inscriptions inédites de Thessalie", RPh 35 (1911b), p. 300-301.

—, PAE (1915), p. 159.

-, Polemon 1 (1929), p. 32-43.

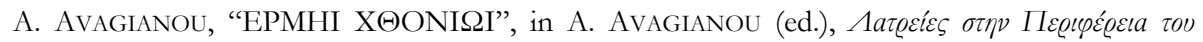

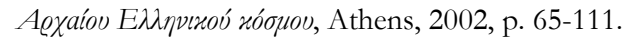

S.C. BAKHUIZEN, "Magnesia unter Makedonischer Suzeränität", in S. BAKHUIZEN et al. (eds), Demetrias V, Bonn, 1987, p. 319-338.

-, A Greek City of the Fourth Century B.C., Rome, 1992.

A. Batziou-Efstathiou, Demetrias, Athens (TAPA), 2002.

—, Y. Pikoulas, "A Senatus Consultum from Demetrias", in G.A. Pikoulas (ed.), Inscriptions and History of Thessaly. New Evidence. Proceedings of the International Symposium in honor of Professor Christian Habicht, Volos, 2006, p. 79-89.

G. CoHen, The Hellenistic Settlements in Europe, the Islands and Asia Minor, Berkeley/London/New York, 1995.

J.-C. Decourt, Th. H. Nielsen, Br. Helly et al., "Thessalia and adjacent regions", in M.H. HANSen, Th. H. Nielsen (eds), An Inventory of Archaic and Classical Poleis. An Investigation conducted by the Copenhagen Polis Centre for the Danish National Research Foundation, Oxford, 2004, p. 676-731.

—, A. Tziafalias, "Cultes et divinités isiaques en Thessalie", in L. Bricault et al. (eds.), Nile into Tiber. Egypt in the Roman World, Leiden, 2007, p. 329-363.
180 SEG 25, 680.
${ }^{181} I G$ IX 2, 1137.
182 IG IX 2, 1136.
183 IG IX 2, 1138.
184 SEG 37, 462.
185 SEG 37, 463. 
V. Gabrielsen, "The Synoikized Polis of Rhodes", in P. Flensted-Jensen, T.H. Nielsen, L. Rubinstein (eds.), Polis and Politics: Studies in Ancient Greek History, Copenhagen, 2000, p. $177-206$.

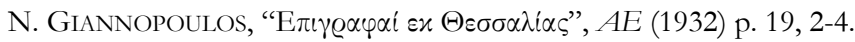

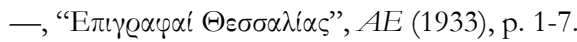

M.H. HANSEN, "The Emergence of Poleis by Synoikismos", in M.H. HANSEN, Th. H. NielseN (eds.), An Inventory of Archaic and Classical Poleis. An Investigation Conducted by the Copenhagen Polis Centre for the Danish National Research Foundation, Oxford, 2004, p. 115-119.

M. Hatzopoulos, Cultes et rites de passage en Macédoine, Athens, 1994.

—, Macedonian Institutions under the Kings. A Historical and Epigraphic Study, Athens, 1996.

—, La Macédoine: géograpbie historique, langues, cultes et croyances, institutions, Paris, 2006.

Br. Helly, "Accord de sympolitie entre Gomphoi et Thamiai (Ithomé)", in E. Crespo, J.L. Garcia Ramon, A. Striano (eds.), Dialectologica Graeca: Actas del II coloquio internacional de dialectologia griega (Miraflores de la Sierra [Madrid], 19-21 de junio de 1991), Madrid, 1993, p. 167200.

—, "Sur quelques monnaies des cites Magn'tes: Euréai, Euryménai, Méliboia, Rhizous", in Coins in the Thessalian Region. Mints, Circulation, Iconography, History, Ancient, Byzantine, Modern. Proceedings of the Third Scientific Meeting (Oßoגós 7), Athens, 2004, p. 101-24

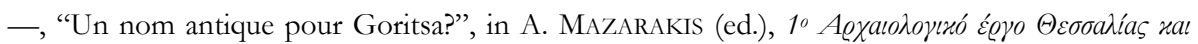

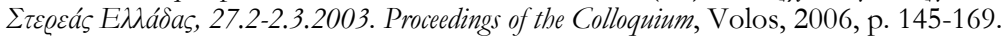

K. Hornung-Bertemes, Terrakotten aus Demetrias (Demetrias 7), Würtzburg, 2007.

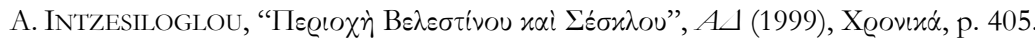

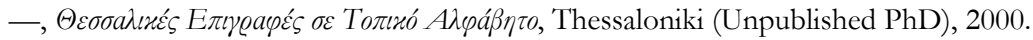

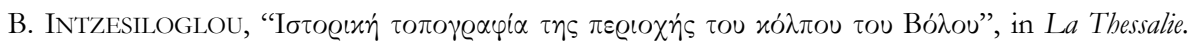
Quinze années de recherches archéologiques, 1975-1990. Bilans et perspectives. Actes du Colloque International. Lyon, 17-22 Avril 1990, vol. II, Athens, 1994, p. 31-56.

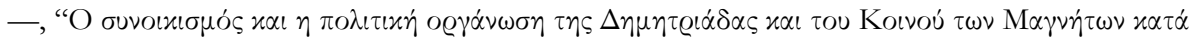

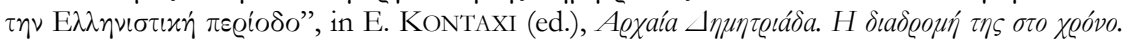
Proceedings of the Conference, Volos, 1996, p. 91-109.

-, "The Inscription of the Kynegoi of Herakles from the Ancient Theatre of Demetrias", in G.A. PIKOUlas (ed.), Inscriptions and History of Thessaly. New Evidence. Proceedings of the International Symposium in honour of Professor Christian Habicht, Volos, 2006, p. 67-77.

S. Kravaritou, "Thessalian Perceptions of Ruler Cult: 'archegetai and ketistai from Demetrias", in P. Martzavou, N. Papazarkadas (eds.), The Epigraphy of the Post-Classical Polis: Papers from the Oxford Epigraphy Workshop, Oxford (OUP) (forthcoming).

—, "Sacred Space and the Politics of Multiculturalism in Demetrias", in M. Melfi, O. Bobou (eds.), Rethinking the Gods: Post-Classical Approaches to Sacred Space. Proceedings of the International Conference held at Oxford, 21-23 September 2011, Oxford (in preparation).

K. LiampI, "Iolkos and Pagasai : Two new Thessalian Mints", NC 165 (2005), p. 23-40.

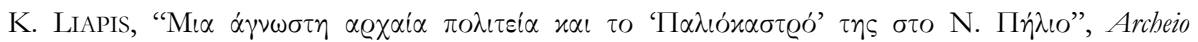
Thessalikon Meleton 13 (2004), p. 83-108.

J. MA, Antiochos III and the Cities of Western Asia Minor, Oxford, 1999.

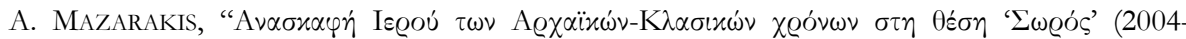

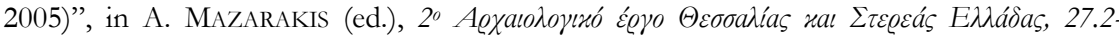
2.3.2006. Proceedings of the Colloquium, Volos, 2009, p. 269-294.

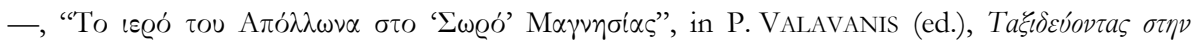

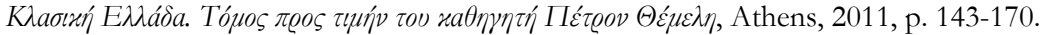

Z. MALAKasioti, "Nea Ionia”, AD 53 (1998), p. 419-23.

A. McDeVITT, Inscriptions of Thessaly. An Analytical Handlist and Bibliography, Hildesheim/New York 1970. 
E. MeYER, "Eine Inschrift von Iolkos", RhM (1936), p. 367-376

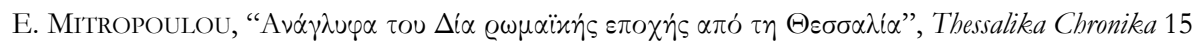
(1984), p. 93-110.

E. Mitropoulou, "The Worship of Asclepios and Hygeia in Thessaly", in La Thessalie. Quinze années de recherches archéologiques, 1975-1990. Bilans et perspectives. Actes du Colloque International. Lyon, 17-22 Avril 1990, vol. II, Athens, 1994, p. 485-500.

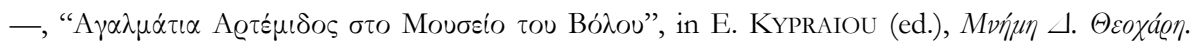
Proceedings of the International Conference, Athens, 1992, p. 326-332.

A. Moustaka, Kulte und Mythen auf thessalische Münzen, Würzburg, 1983.

M.P. Nillson, Cults, Myths, Oracles and Politics in Ancient Greece, Lund, 1951.

D. Pantermalis, $\triangle$ iov: $\eta$ avaxá $u \psi \eta$, Athens, 1999.

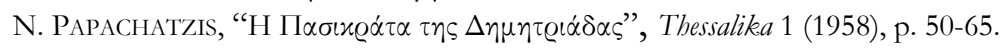

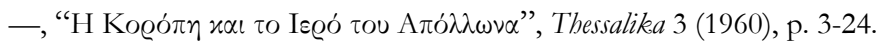

R. PARKer, "Subjection, Synoecism and Religious Life", in P. FunKe, N. Luraghi (eds.), The Politics of Ethnicity and the Crisis of the Peloponnesian League, Harvard et al., 2009, p. 183-214.

G. REGER, “The Myconian Synoikismos”, REA 103 (2001), p. 145-181.

—, "Sympoliteiai in Hellenistic Asia Minor", in S. Colvin (ed.), The Greco-Roman East: Politics, Culture Society, Cambridge, 2004, p. 732-793.

E. Rogers, The Copper Coinage of Thessaly, London, 1932.

A. SChNApp, "Peut-on parler d'une Archéologie de la religion grecque ?", in R.F. Docter, E.M. Moormann (eds.), Proceedings of the XVth International Conference of Classical Archaeology, Amsterdam, 1999, p. 34-39.

D. SEAR, Greek Coins and their Values, London, 1978.

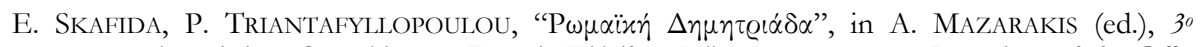

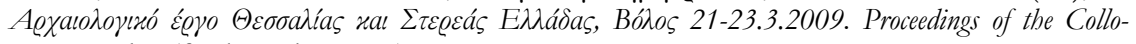
quium, Volos (forthcoming 2012).

F. StÄHlin, E. Meyer, A. Heidner (eds.), Pagasai und Demetrias, Berlin/Leipzig, 1934.

M. Stamatopoulou, Burial Customs in Thessaly in the Classical and Hellenistic Periods, PhD. Oxford, 1999.

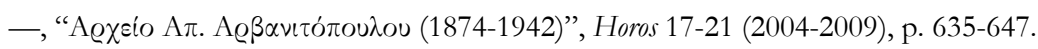

-, "Ouaphres Horou, an Egyptian priest of Isis from Demetrias", in D. KuRTz et al. (eds.), Essays in Classical Archaeology for Eleni Chatzivassiliou 1977-2007, Oxford, 2008, p. 249-257.

—, The Archaeology of Burial in Thessaly in the Classical and Hellenistic Periods, Oxford (in preparation).

D. Theocharis, G. Chourmouziadis, $A D$ (1968), p. 269.

G. ThÜr, H. TAuber, Prozessrechtliche Inschriften der griechischen Poleis: Arkadien, Vienna, 1994.

K. TRÜMPY, Untersuchungen zu den altgriechischen Monatsnamen und Monatsfolgen, Heidelberg, 1997.

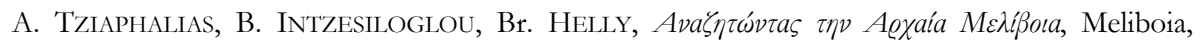
2010.

A.J.B. WACE, “The Topography of Pelion and Magnesia”, JHS 26 (1906), p. 143-68.

—, J.P. Droop, "Excavations at Theotokou, Thessaly", ABS A 13 (1906-7), p. 309-327.

C.B. WelLes, Royal Correspondence in the Hellenistic Period, London, 1934.

P. WOLTERs, "Recherches sur les st'les funéraires hellénistiques de Thessalie", in La Thessalie. Actes de la Table-Ronde, 21-24 juillet 1975, Lyon, 1979, p. 81-110. 